\title{
Analysis of Performance and Satisfaction with The 5 Fields of Pt Adaro Indonesia CSR Program In 2019
}

\author{
Aan Nurhadi ${ }^{1}$, Lenie Marlinae², Tien Zubaidah ${ }^{3}$, Muhamad Ratodi $^{4}$, Muhammad Azmi Maruf ${ }^{5}$ \\ ${ }^{1}$ Corporate Social Responsibility PT Adaro Indonesia, Balangan, \\ ${ }^{2}$ Department of Environmental Health, Public Health Study Program, Faculty of Medicine, University of Lambung Mangkurat \\ ${ }^{3}$ Ministry of Environmental Health, Polytechnic of Environmental Health, Ministry of Health, Republic of Indonesia \\ ${ }^{4}$ Faculty of Psychology and Health, Sunan Ampel State Islamic University \\ ${ }^{5}$ Public Health Study Program, Faculty of Medicine, University of Lambung Mangkurat
}

DOI: 10.29322/IJSRP.10.11.2020.p10732

http://dx.doi.org/10.29322/IJSRP.10.11.2020.p10732

\begin{abstract}
Performance refers to a result of human resource activities that exist in the organization together to bring the final result based on the quality level and predetermined standards. The purpose of this study was to analyze the relationship between performance and satisfaction of the beneficiaries of the 5 CSR areas of PT. Adaro Indonesia in 2019. This type of research is analytic observational using a survey method through a cross-sectional approach, in which data concerning the independent and dependent variables can be collected at one time. The population in this study was drawn from the beneficiaries of PT Adaro Indonesia's CSR program in 2019. The sample is the beneficiaries of PT Adaro Indonesia's CSR program which is divided into 5 fields, consisting of 26 clusters / programs, 907 respondents.Based on analysis of the relationship between performance and interest shows that the funding indicator and officer behavioris something that must be maintained in the implementation of programs carried out by the CSR of PT. Adaro Indonesia.Suggestion, companies need to pay more attention to indicators that lie in secondary priority and tertiary priority even though in fact they have been implemented well by the company.
\end{abstract}

Index Terms- Performance, Satisfaction, CSR, Adaro Indonesia

\section{INTRODUCTION}

$\mathrm{T}$ he importance of providing good and satisfying public services is a major concern in today's era. Public service performance is one of the strategic dimensions in assessing the success of implementing public services. The higher the concern of an organization / agency / company in meeting the interests of the community, the better the performance of public services (Sutrisno and Mariyono, 2016).

Performance appraisal is very important for a company. With this performance appraisal, a company can see the extent to which human factors can support the goals of a company organization. Performance appraisals can motivate employees to be motivated to work better. Therefore we need a proper and consistent performance appraisal. The quality of a company organization through CSR in the field of public services comes from human resources who are one of the keys to success in advancing a company. The success and performance of a person in a field of work is largely determined by the level of competence, integrity, professionalism and work ethic of the officers. In addition, existing human resources can create and develop a conducive climate and work culture. Performance appraisal is very important for an organization. With this performance appraisal an organization can see the extent to which human factors can support the goals of an organization. Performance appraisals can motivate employees to be motivated to work better. Therefore, we need a proper and consistent performance appraisal.

The success of a company is greatly influenced by the performance of its employees. Performance is work performance, namely the comparison between real work results and the work standards set (Dessler, 1992). Every organization strives to improve the performance of its employees in order to achieve the goals set by the organization. Various ways can be taken by organizations in improving employee performance, including realizing employee job satisfaction through organizational culture and leadership styles that are in accordance with the expectations of employees and society.

In general, what is meant by satisfaction is the feeling of pleasure or disappointment of someone who comes after comparing product performance with the desired results (Kotler, 2005). If the quality of service exceeds expectations, the customer / consumer will feel very satisfied. The opinion above concluded that satisfaction is the level of a person's feelings after comparing the perceived performance with expectations. 
ISSN 2250-3153

PT Adaro Indonesia, which is one of the coal companies in South Kalimantan.PT Adaro Indonesia as a leading coal mining company always complies with government policies. This includes the obligation to implement CSR programs in operational villages. The CSR program is not only carried out by Adaro, but also by its partners. The company synergizes with the government to contribute to human development since the company operates.

PT Adaro Indonesia's CSR program is divided into 5 programs, namely economy, education, health, socio-culture and environment with the main target in the villages in the company's operational areas, 2 Provinces, 6 Districts, 15 Districts and 65 Villages according to the needs of the surrounding communities who are affected or have the opportunity to feel impact of industrial processes. The five pillars aim at creating an independent post-mining community in the sense of economic independence, intellectual independence and management independence with a value system of honesty, justice, simplicity, equality and non-discrimination based on the principles of participation, democracy, transparency, accountability and partnership.

CSR is not only a company's creative activity and is not limited to compliance with legal regulations alone, but is a company's commitment to building a better quality of life with related stakeholders (government and society), especially the community around the company. Because the role of CSR is currently increasingly important for the community around the company in an effort to balance development, be it economic, social, cultural health and the environment.

Measurement of IKM is one of the instruments used to measure the level of service performance in the community based on the Regulation of the Minister of Administrative Reform and Bureaucratic Reform of the Republic of Indonesia Number 14 of 2017 concerning Guidelines for Preparing Community Satisfaction Surveys. This instrument provides an opportunity for the public to be involved in periodically assessing the Five Pillars Performance of PT Adaro Indonesia's CSR as a basis for further planning. A satisfied community is a very valuable asset because if the community is satisfied, it will continue to empower the company and will form a good perception to others about their good experiences (Pohan, 2007).

The elements will be the focus in implementing the Community Satisfaction Survey which consists of 9 elements consisting of requirements; systems, mechanisms and procedures; turnaround time; fees / rates; product type service specification; executive competence; implementing behavior; the handling of complaints; as well as facilities and infrastructure.

Measurement of the Community Satisfaction Index (IKM) is also useful for companies to support the preparation of future community development and empowerment plans, in accordance with the Minister of Energy and Mineral Resources Decree Number: 1824 / K / 30 MEM / 2018 concerning Guidelines for Implementation of Community Development and Empowerment (PPM), in addition to The IKM is also one of the items that must be in place for the fulfillment of the PROPER parameters of the Ministry of Environment and Forestry (KLHK) in accordance with the Minister of Environment and Forestry Regulation Number: 3/2013 and for the fulfillment of CSR Key Performance Indicators (KPIs) in making analytical bases for decision making with focus on things that are considered the most important and can be measured.

\section{METHODS}

This research is analytic observational using a survey method through a cross-sectional approach, in which data concerning independent and dependent variables can be collected at one time. The population in this study was drawn from the beneficiaries of the CSR program. The instrument or tool used in this research is a public perception questionnaire based on the Community Satisfaction Index (CSI) according to the Decree of the Minister of State Apparatus Empowerment No. KEP / 25 / M.PAN / 2/2004 concerning General Guidelines for Preparation of Community Satisfaction Index.

The analytical tool used to analyze the level of community satisfaction in implementing CSR is Importance Performance Analysis (IPA), which consists of three components, namely gap analysis, suitability analysis, and quadrant analysis. Gap analysis is used to determine the gap between performance / implementation with the expectations / interests of the community towards the attributes of the service quality dimensions of CSR programs. The suitability analysis is used to determine the priority order of the attributes that are priority improvements based on the percentage comparison between the performance value and the importance level of the CSR program service quality dimension attributes. Quadrant analysis is used to determine the community's response to the attributes mapped based on the level of importance and performance of the attributes of the service quality dimensions of CSR programs.

This publication is licensed under Creative Commons Attribution CC BY.

http://dx.doi.org/10.29322/IJSRP.10.11.2020.p10732

WWW.ijsrp.org 
ISSN 2250-3153

\section{RESULTS AND DISCUSSION}

The calculation of the average weight of each attribute regarding the level of importance (importance) and user ratings of service performance (performance) can be seen in Table 1 below:

Table 1. Analysis of the Relationship between Interests and Performance

\begin{tabular}{llcccc}
\hline \multirow{2}{*}{ No. } & \multirow{2}{*}{ Scope } & \multicolumn{2}{c}{ Interest } & \multicolumn{2}{c}{ Performance } \\
\cline { 3 - 5 } & & Score & Category & Score & Category \\
\hline 1 & Terms of Service & 3.36 & Urgent & 3.23 & Satisfied \\
2 & Systems, mechanisms, procedures & 3.32 & Urgent & 3.22 & Satisfied \\
3 & Service turnaround time & 3.32 & Urgent & 3.22 & Satisfied \\
4 & Funding & 3.41 & Urgent & 2.25 & Satisfied \\
5 & Products / service results & 3.33 & Urgent & 3.25 & Satisfied \\
6 & Implementing competence & 3.33 & Urgent & 3.25 & Satisfied \\
7 & Implementing behavior & 3.38 & Urgent & 3.31 & Satisfied \\
8 & The handling of complaints & 3.34 & Urgent & 3.24 & Satisfied \\
9 & Facilities and infrastructure & 3.32 & Urgent & 3.20 & Satisfied \\
\hline
\end{tabular}

Source: IKM Survey of ADARO CSR Program 2019

Based on the table above, further analysis is needed to determine the priority scale in an effort to improve each of the existing attributes. The next step is mapping the importance and performance levels into a Cartesian Importance-Performance Analysis diagram. In this technique, respondents are asked to assess the level of importance and performance of the company, then the average value of the importance and performance level is analyzed on the Importance Performance Matrix, where the $\mathrm{x}$-axis represents performance while the y-axis represents the importance of the results, a matrix consisting of four is formed. quadrant where each quadrant describes the priority scale in policy making in the form of improving performance or maintaining company performance (Laricha et al, 2018).

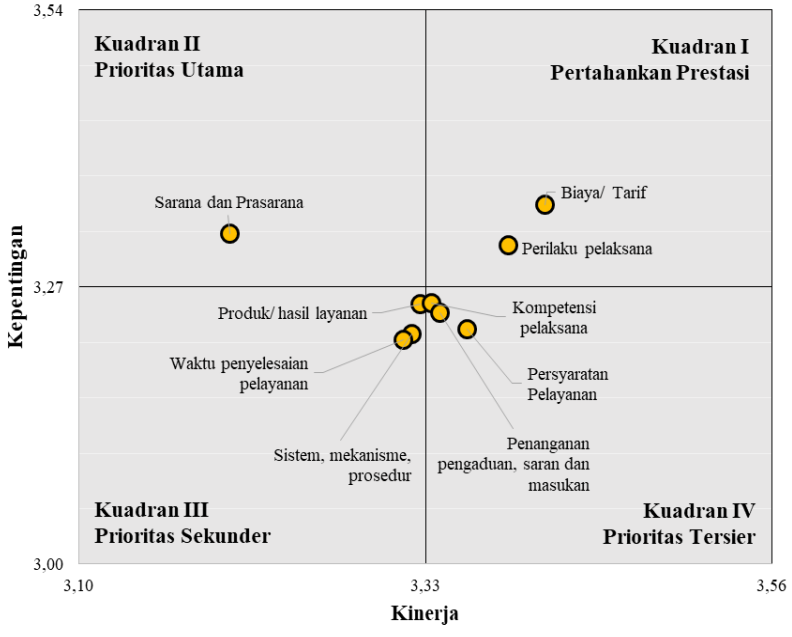

Image 1.Importance Performance Matrix

Table 2 below illustrates the distribution of performance data and interests based on the division of quadrants:
Table 2. Categories Importance Performance Matrix

\begin{tabular}{|c|c|c|}
\hline Scope & Quadrant & Information \\
\hline Terms of Service & IV & Tertiary Priority \\
\hline $\begin{array}{l}\text { Systems, mechanisms, } \\
\text { procedures }\end{array}$ & III & $\begin{array}{l}\text { Secondary } \\
\text { Priority }\end{array}$ \\
\hline Service turnaround time & III & $\begin{array}{l}\text { Secondary } \\
\text { Priority }\end{array}$ \\
\hline Funding & I & $\begin{array}{l}\text { Maintain } \\
\text { Achievement }\end{array}$ \\
\hline Products / service results & III & $\begin{array}{l}\text { Secondary } \\
\text { Priority }\end{array}$ \\
\hline Implementing competence & IV & Tertiary Priority \\
\hline Implementing behavior & I & $\begin{array}{l}\text { Maintain } \\
\text { Achievement }\end{array}$ \\
\hline $\begin{array}{l}\text { Handling complaints, } \\
\text { suggestions and input }\end{array}$ & IV & Tertiary Priority \\
\hline Facilities and infrastructure & II & Main priority \\
\hline
\end{tabular}

Source: IKM Survey of ADARO CSR Program 2019

In the results of the analysis of the relationship between performance and interest, it can be seen that the community considers that 9 indicators are important in implementing programs carried out by CSR ADARO with the main interest affecting the performance of CSR officers of PT. Adaro.

Analysis using Importance Performance Matrixis performed to determine the position of each attribute that has been assigned to the two-dimensional plane (X-axis and $\mathrm{Y}$-axis) on the Cartesian diagram. The positions of these attributes will show four things related to the importance level and performance level of each of the previously defined attributes. This analysis can be used 
as a strategic step in an effort to increase community satisfaction and determine the priority of activities that need to be carried out or perhaps activities that are not necessary. Based on Figure 1 it explains:

1. Quadrant 1 (Maintain Achievement) shows that funding and staff behavior are perceivedmostimportant and satisfying to the community that has been implemented well by the company. The factors / attributes that exist in this quadrant must be maintained because these factors make the company superior according to the beneficiary communityprogram CSR.

2. Quadrant II (Main Priority) indicates that facilities and infrastructure are considered important by the community and has been implemented well by the company.

3. Quadrant III (Secondary Priority) indicates that the system, mechanism, procedure and time of completion of services as well as product attributes / service outcomes are notnot really penting (secondary) for the beneficiary communityCSR program, but in fact it has been implemented well by the company.

4. Quadrant IV (Tertiary Priority) shows that the service requirements, the competence of executors and the attributes for handling complaints, suggestions andit is not an important thing (tertiary), but in fact the company has performed well and is very concerned about these indicators.

\section{CONCLUSION}

1. Analysis of the relationship between performance and interests shows that the community considers that the funding indicator is something that must be maintained by CSR of PT. Adaro Indonesia.

2. Analysis of the relationship between performance and interests shows that the community considers that indicators facilities and infrastructure are considered important by the community and have been implemented properly by the company.

3. Analysis of the relationship between performance and interests shows that society considers is not something that doesn't really matter for indicators systems, mechanisms, procedures and time for completion of services as well as product attributes / service outcomes, but have been implemented properly by the company.

4. Analysis of the relationship between performance and interests shows that the community considers that indicators Service requirements, executive competence and complaint handling, suggestions and input are not important, but have been implemented properly by the company.

\section{REFERENCES}

[1] Dessler, Garry, 2006, Manajemen Sumber Daya Manusia, Jakarta: Indeks.

[2] Irwanto AK, Prabowo A. 2009. Kajian efektivitas program corporate social responsibility (CSR) Yayasan Unilever Indonesia. Jurnal Manajemen1(1).
[3] Kotler, philip dkk, 2000, Manejemen Pemasan Jasa di Indonesia Analis Perencanaan, Implementasi dan Pengendalian (edisi pertama) Jakarta: Salemba Empat. Nirmaya GC, Muflikhati I, Simanjuntak M. 2014. Pengaruh Program Corporate Social Responsibility (CSR) Terhadap Kesejahteraan Keluarga Di Sekitar Tambang. Jurnal Ilmu Keluarga \& Masyarakat. Jan 1;7(1):19-29.

[4] Laricha, Lithrone., Kosasih, Wilson., Permai, R., Tri., 2018. Pengukuran dan Analisis Indeks Kepuasan Masyarakat di Kantor Imigrasi Jakarta. Jurnal Ilmiah Teknik Industri (2018). Vo. 6 No.1, 35-42.

[5] Pohan IS. 2007. Jaminan mutu layanan kesehatan: dasar-dasar pengertian dan penerapan. Jakarta: EGC

[6] Sutowo IR. 2013. Analisis Indeks Kepuasan Masyarakat dan Manfaat Ekonomi Program Corporate Social Responsibility (CSR) Chevron Geothermal Salak, Ltd. Bidang Ekonomi di Kecamatan Pamijahan, Kabupaten Bogor.

[7] Wijono D. 2008 . Paradigma dan metodologi penelitian kesehatan. Surabaya: CV Duta Prima Airlangga.

[8] Sutrisno, Edi., Mariyono, Joko., 2016. Pengaruh Kualitas Pepelayanan dan Kinerja Pegawai Terhadap Kepuasan Masyarakat (Keluarganya Warga Binaan Pemasyarakatan) Pada Lembaga Pemasyarakatan Kelas Iib Slawi. Available From:

Https://Www.Researchgate.Net/Publication/321600892_P ENGARUH_KUALITAS_PEPELAYANAN_DAN_KINE RJA_PEGAWAI_TERHADAP_KEPUASAN_MASYAR AKAT_Keluarganya_Warga_Binaan_Pemasyarakatan_PA DA_LEMBAGA_PEMASYARAKATAN_KELAS_IIB_S LAWI [accessed Oct 04 2020].

\section{AUTHORS}

First Author - Aan Nurhadi, Corporate Social Responsibility PT Adaro Indonesia, Balangan

Second Author - Lenie Marlinae, Department of Environmental Health, Public Health Study Program, Faculty of Medicine, University of Lambung Mangkurat

Third Author - Tien Zubaidah, Ministry of Environmental Health, Polytechnic of Environmental Health, Ministry of Health, Republic of Indonesia

Fourth Author - Muhamad Ratodi, Faculty of Psychology and Health, Sunan Ampel State Islamic University

Fifth Author - Muhammad Azmi Maruf, Public Health Study Program, Faculty of Medicine, University of Lambung Mangkurat

Correspondence Author - Aan Nurhadi, Corporate Social Responsibility PT Adaro Indonesia, Balangan, aan.nurhadi06@gmail.com 